JURNAL PENDIDIKAN, p-ISSN 2715-095X, e-ISSN 2686-5041

Volume 29, No.3, Nopember 2020 (313-320)

Online: http://journal.univetbantara.ac.id/index.php/jp

\title{
Penerapan Model Pembelajaran Make a Match untuk Meningkatkan Prestasi Belajar Bahasa Inggris
}

\author{
Darmi \\ Guru SMP Negeri 1 Bulu Kabupaten Sukoharjo, Email: aidahdarmi@yahoo.co.id
}

\begin{abstract}
Abstrak: Tujuan penelitian tindakan kelas ini adalah untuk meningkatkan prestasi belajar bahasa Inggris siswa melalui model pembelajaran kooperatif tipe make a match pada siswa kelas IXC semester 1 SMP Negeri 1 Bulu tahun pelajaran 2019/2020. Penelitian ini dilaksanakan pada bulan Juli sampai Desember 2019 di SMP Negeri 1 Bulu. Subjek penelitian ini adalah siswa kelas IXC sebanyak 32 siswa. Penelitian Tindakan Kelas ini dilakukan dalam dua siklus. Teknik pengumpulan data menggunakan teknik dokumentasi, observasi, dan tes tertulis. Alat pengumpulan data berupa lembar pengamatan, butir soal tes, dan dokumen daftar nilai. Analisis data menggunakan analisis deskriptif komparatif yang dilanjutkan refleksi. Setiap siklus terdiri dari empat langkah, yaitu: (1) Perencanaan, (2) Pelaksanaan Tindakan, (3) pengamatan, dan (4) Refleksi. Hasil penelitian menunjukkan adanya peningkatan prestasi belajar siswa, nilai bahasa Inggris rata-rata prestasi belajar bahasa Inggris siswa mengalami peningkatan yaitu sebelum tindakan sebesar 70,14, pada siklus I sebesar 75,25 dan pada siklus II sebesar 803. Selain itu, persentase ketuntasan belajar siswa juga meningkat, yaitu sebelum tindakan sebesar $53,1 \%$, siklus I sebesar $71,8 \%$ dan siklus II sebesar 90,6\%. Sehingga dapat disimpulkan bahwa "Model pembelajaran kooperatif tipe make a match dapat meningkatkan prestasi belajar menulis teks procedure bahasa Inggris siswa kelas IXC semester 1 SMP Negeri 1 Bulu tahun pelajaran 2019/2020".
\end{abstract}

Kata-kata Kunci: Prestasi Belajar Menulis Teks Procedure, Model Pembelajaran Make a match

\section{The Application of Make a Match Learning Model to Improve the Achievement of English}

\section{Darmi}

The Teacher of SMP Negeri 1 Bulu Sukoharjo Regency,Email: aidahdarmi@yahoo.co.id

\begin{abstract}
The purpose of this classroom action research is to improve students' learning achievement of English through learning model of Make a match in grade IXC students of semester 1 of SMP Negeri 1 Bulu in the 2019/2020 school year. This research was conducted from July to December 2019 in SMP Negeri 1 Bulu. The subjects of this study were students of class IXC as many as 32 students. This research is a Classroom Action Research conducted in two cycles. Data collection techniques used documentation, observation, and written tests. Data collection tools are observation sheets, test items, and value list documents. Data analysis using comparative descriptive analysis is followed by reflection on each cycle consists of four steps, namely: (1) Planning, (2) Action Implementation, (3) observation, and (4) reflection. The results of this study indicate an increase in learning achievement of English Subject students. This can be seen from the average score of learning achievement of English Sujec tstudents also experienced an increase before the action of 70.1, in the first cycle of 75.2 and on the second cycle of 80. In addition, the percentage of students' learning mastery, example before the action of $53.1 \%$, in the first cycle of $71.8 \%$ and in the second cycle of $90.6 \%$. So it can be concluded
\end{abstract}


that "Cooperative learning model of make a matchcan improve the learning achievement of Englishstudents of class IXC semester 1 SMP Negeri 1 Bulu in 2019/2020 academic year".

Keywords: Learning Achievement of English, Learning Model of make a match

\section{Pendahuluan}

Penguasaan kemampuan Bahasa Inggris (language skill) merupakan sebuah syarat mutlak yang harus dimilki siswa di era teknologi komunikasi dan globalisasi di zaman yang serba canggih ini. Pembelajaran bahasa Inggris (language learning) di jenjang SMP merupakan materi pokok sebagai bagian dari fungsi pengembangan diri siswa dalam bidang ilmu pengetahuan, teknologi, dan seni yang diharapkan setelah menamatkan studinya, mereka mampu tumbuh dan berkembang menjadi individu yang cerdas, terampil, dan berkepribadian sebagai bekal hidup di masa mendatang. Penguasaan materi pelajaran bahasa Inggris pada jenjang SMP meliputi empat ketrampilan berbahasa, yaitu: menyimak, berbicara, membaca, dan menulis. Semua itu harus didukung oleh unsur-unsur bahasa lainnya, seperti kosa kata, tata bahasa, makna, dan sebagainya. Dari keempat ketrampilan berbahasa itu, writing (menulis) merupakan salah satu kemampuan berbahasa yang dirasa menjadi masalah bagi siswa dalam proses pembelajaran bahasa Inggris. Banyak guru bahasa Inggris yang menyadari bahwa bahasa Inggris dianggap sebagai pelajaran yang membosankan oleh sebagian besar siswa. Sehingga banyak siswa yang mengeluh tentang kesulitan belajar dalam mengikuti pembelajaran bahasa Inggris. Dari hasil pengamatan, nilai rata-rata ulangan harian siswa dalam belajar bahasa Inggris masih rendah dan masih banyak yang belum mencapai KKM. Hal ini dibuktikan dengan nilai yang didapat siswa kelas IXC SMP Negeri 1 Bulu mendapat nilai dibawah 75 (KKM).

Guru kurang kreatif dan inovatif dalam menyampaikan pelajaran, dimana guru masih menggunakan metode ceramah dan kurang melibatkan siswa sehingga siswa menjadi cepat bosan bahkan terkadang siswa hanya duduk, diam, danbahkan tidur, tidak ada gagasan atau ide yang ingin diungkapkan. Padahal sering kali dalam proses pembelajaran adanya kecenderungan siswa tidak bertanya pada guru meskipun sebenarnya siswa belum mengerti materi yang sedang diajarkan. Hal ini berakibat pada hasil belajar bahasa Inggris siswa masih rendah. Berdasarkan hasil pengamatan peneliti selaku guru bahasa Inggris kelas IXC SMP Negeri 1 Bulu, masalah yang dihadapi oleh siswa sejauh ini adalah kurangnya kekooperatifan dan rendahnya prestasi belajar siswa, salah satunya adalah materi wrting (menulis) teks procedure. Karena pada ketrampilan ini siswa harus menguasai unsur-unsur bahasa yang memadai.Hal ini dapat dilihat dari kegiatan belajar mengajar di kelas IXC dengan KKM 75, nilai rata-rata hasil ulangan harian bahasa Inggrismateri wrting (menulis) teks procedure di kelas IXC masih di bawah KKM, yaitu 70,1 dengan persentase ketuntasan sebesar 53,1\%. Selain itu, pada kegiatan pembelajaran di dalam kelas siswa hanya bersikap pasif, sedangkan yang kooperatif adalah guru. Sehingga siswa merasa bosan dan kurang termotivasi dalam belajar bahasa Inggris. Untuk itu guru diharapkan dapat menciptakan suasana kelas yang menyenangkan sehingga siswa dapat termotivasi dalam belajar bahasa Inggris dan dapat menambah kekooperatifan siswa dalam pembelajaran. Kurangnya suasana kelas yang menyenangkan dan perlu adanya suatu model pembelajaran yang inovatif dan kreatif yang dapat menumbuhkan semangat belajar bahasa Inggris dan memperkuat daya ingat siswa terhadap materi yang dipelajari sehingga dapat menunjang terciptanya kegiatan belajar mengajar yang kondusif. Upaya untuk meningkatkan prestasi belajarbahasa Inggris siswa adalah dengan menggunakan model pembelajaran yang 
menarik minat belajar siswa. Untuk itu peneliti menerapkaan model pembelajaran kooperatif tipe Make a match,yaitu model pembelajaran yang dapat menciptakan suasana kelas menjadi menarik dan menyenangkan karena setiap kelompok yang dapat menjawab benar maka siswa tersebut akan mendapat reward yang disukai. Make a match adalah salah satu model pembelajaran yang mendorong siswa untuk ikut kooperatif dalam belajar.

Menurut Suprijono (2009: 54) pembelajaran kooperatif sesuai dengan fitrah manusia sebagai makhluk sosial yang penuh ketergantungan dengan orang lain, mempunyai tujuan dan tanggung jawab bersama, pemberian tugas dan rasa senasib. Dengan memanfaatkan kenyataan itu, belajar kelompok secara kooperatif siswa dilatih dan dibiasakan bertukar pengetahuan, tanggung jawab, saling membantu dan berlatih berinteraksi-komunikasisosialisasi karena pembelajaran kooperatif adalah miniatur dari hidup bermasyarakat, dan belajar menyadari kekurangan dan kelebihannya masing-masing. Pembelajaran Kooperatif merupakan strategi belajar dengan sejumlah siswa sebagai anggota kelompok kecil yang tingkat kemampuannya berbeda. Dalam menyelesaikan tugas kelompoknya, setiap siswa anggota kelompok harus saling bekerja sama dan saling membantu untuk memahami materi pelajaran. Menurut Isjoni (2007:12) menyatakan bahwa dalam pembelajaran kooperatif, belajar dikatakan belum selesai jika salah satu teman dalam kelompok belum menguasai bahan pelajaran. Teknik belajar mengajar make a match (Mencari Pasangan) dikembangkan oleh Lorna Curran (1994). Salah satu keunggulan teknik ini adalan siswa mencari pasangan sambil belajar mengenai suatu konsep atau topik dalam suasana yang menyenangkan. Teknik ini bisa digunakan dalam semua mata pelajaran dan untuk semua tingkat usia anak didik.Langkah-Langkahnya sebagai berikut: (1) Guru menyiapkan beberapa kartu yang berisi beberapa konsep atau topik yang cocok untuk sesi review, satu bagian kartu merupakan soal dan bagian lain berupa jawaban; (2) Setiap siswa mendapat satu buah kartu yang bertuliskan soal/jawaban; (3) Tiap siswa memikirkan jawaban/soal dari kartu yang dipegang; (4) Setiap siswa mencari pasangan yang mempunyai kartu yang cocok dengan kartunya(soal jawaban); (5) Setiap siswa yang dapat mencocokkan kartunya sebelum batas waktu diberi poin; (6) Jika siswa tidak dapat mencocokkan kartunya dengan kartu temannya (tidak dapat menemukan kartu soal/kartu jawaban) akan mendapatkan hukuman yang telah disepakati bersama; (7) Setelah satu babak kartu dikocok lagi agar siswa mendapat kartu yang berbeda dari kartu sebelumnya, demikian seterusnya; dan (8) Guru bersama-sama dengan siswa membuat kesimpulan terhadap materi yang baru saja dipelajari. Berdasarkan uraian di atas, dapat dirumuskan permasalahan sebagai berikut: "Apakah model pembelajaran kooperatif tipe make a matchdapat meningkatkan prestasi belajar Bahasa Inggris siswa kelas IXC semester 1 SMP Negeri 1 Bulu tahun pelajaran 2019/2020 ?". Tujuan penelitian ini adalah untuk meningkatkan prestasi belajar bahasa Inggrisdengan menerapkan pembelajaran kooperatif tipe make a matchpada siswa kelas IXC semester 1 SMP Negeri 1 Bulu tahun pelajaran 2019/2020. Prestasi belajar Bahasa Inggris dibatasi pada materi menulis teks procedure.

\section{Metode Penelitian}

Penelitian ini adalah Penelitian Tindakan Kelas (PTK). PTK merupakan suatu pencermatan terhadap kegiatan yang sengaja dimunculkan, dan terjadi dalam sebuah kelas (Arikunto, 2010: 130).Penelitian ini dilaksanakan di SMP Negeri 1 Bulu.Tahap-tahap pelaksanaan kegiatan dilakukan selama kurang lebih enam bulan yaitu sejak bulan Juli sampai dengan Desember 2019. Peneliti sebagai guru SMP Negeri 1 Bulu bertindak sebagai subjek yang melakukan tindakan kelas. Teman sejawat sesama guru mata pelajaran bahasa Inggris sebagai observer. Kepala Sekolah bertindak sebagai subjek yang membantu 
dalam perencanaan dan pengumpulan data. Subjek yang menerima tindakan adalah siswa kelas IXC SMP Negeri 1 Bulu semester 1 tahun pelajaran 2019/2020 sebanyak 32 siswa. Teknik pengumpulan data yang digunakan adalah: tes, observasi dan dokumentasi. Tes adalah serentetan pertanyaan atau latihan serta alat lain yang digunakan untuk mengukur keterampilan, pengetahuan inteligensi, kemampuan atau bakat yang dimiliki oleh individu dan kelompok (Arikunto, $2010: 193$ ). Tes digunakan adalah jenis tes hasil(achievement test) berupa kuis individu.Tes ini digunakan untuk mengukur pencapaian siswa setelah mempelajari materi. Hal ini dapat juga sebagai alat untuk mengetahui tingkat pemahaman siswa setelah mempelajari materi Menulis teks procedure dengan menggunakan model pembelajaran kooperatif tipe make a match. Tes yang digunakan adalah tes uraian menjodohkan kalimat acak jawabannya berupa teks berbentuk procedure Lorna Curran (1994). Observasi atau pengamatan dilakukan guna memperoleh data yang akurat, dengan menggunakan lembar observasi. Lembar observasi digunakan untuk memonitor dan mengevaluasi setiap tindakan agar kegiatan observasi tidak terlepas dari konteks permasalahan dan tujuan penelitian. Observasi yang digunakan adalah observasi sistematis, yaitu observasi yang dilakukan oleh pengamat dengan menggunakan pedoman sebagai instrumen pengamatan dan observasi non-sistematis yang dilakukan dengan tidak menggunakan instrumen pengamatan.Dokumentasi diperoleh dari hasil kuis siswa, lembar observasi, lembar wawancara, catatan lapangan, daftar siswa, dan foto-foto selama proses kegiatan belajar mengajar. Dokumentasi ini dimaksudkan adalah sebagai bukti-bukti konkret dari penelitian tindakan kelas tersebut. Instrumen yang digunakan dalam penelitian berupa tes, lembar observasi dan lembar dokumentasi. Tes berbentuk tes tertulis maupun lisan yang dilakukan dalam post test dan kuis individu. Tes ini digunakan untuk mengetahui sejauh mana peningkatan prestasi belajar dengan penerapan model pembelajaran kooperatif tipe make a match.Lembar Observasi, digunakan lembar observasi pelaksanaan pembelajaran kooperatif tipe make a match. Lembar dokumentasi bertujuan untuk mengetahui data siswa selama kegiatan penelitian berlangsung.Lembar dokumentasi ini berupa, foto-foto kegiatan pembelajaran, daftar hadir kegiatan pembelajaran, daftar hadir, daftar nilai, kartu pasangan soal/jawaban dan sebagainya. Indikator keberhasilan kinerja dalam penelitian ini adalah: (1) siswa dianggap mencapai ketuntasan belajar apabila mencapai lebih dari atau sama dengan KKM 75; (2) pembelajaran dianggap berhasil apabila tingkat ketuntasan kelas mencapai lebih dari atau sama dengan $90 \%$; dan (3) pembelajaran dianggap berhasil apabila siswa secara klasikal rata-rata mencapai lebih dari atau sama dengan 80 .

\section{Hasil Penelitian}

Deskripsi data hasil penelitian yang telah dilakukan di kelas IXC SMP Negeri 1 Bulu adalah sebagai berikut. Berdasarkan observasi awal di kelas IXC mata pelajaran Bahasa Inggrisdengan materimenulis teks procedure diperoleh data, dari 32 siswa yang mencapai nilai KKM sebanyak 17 siswa $(53,1 \%)$, dengan nilai rata-rata kelas sebesar 60,8.Penelitian ini dilakukan dengan indikator kinerja nilai rata-rata tes siswa sekurang-kurangnya 80,0 dan banyak siswa dengan nilai di atas KKM yaitu $\geq 75,0$ mencapai $\geq 85 \%$. Berdasarkan pengalaman peneliti sebagai guru bahasa Inggris kelas IXC, guru masih mendominasi kegiatan pembelajaran dan siswa cenderung tidak kooperatif.Salah satu solusi yang dikembangkan adalah penggunaan model pembelajaran yang baru yaitu dengan model pembelajaran kooperatif tipe make a match. Dengan penggunaan model pembelajaran tersebut diharapkan akan menciptakan suasana belajar yang berbeda, bervariasi dan menyenangkan sehingga dapat menarikperhatian siswa, meningkatkan kekooperatifan 
siswa yang muara akhirnya meningkatkan prestasi belajar siswa. Tindakan kelas siklus I dilaksanakan pada har Rabu, 29 Agustus 2019 di SMP Negeri 1 Bulu kelas IXC. Setelah langkah apersepsi dilanjutkan dengan penyampaian materi teks procedure dengan model pembelajaran kooperatif tipe make a match. Berdasarkan hasil evaluasi pada siklus I menunjukkan adanya peningkatan prestasi belajar siswa. Prestasi belajar siswa sebanyak 23 siswa mencapai nilai $\mathrm{KKM}$ atau $71,8 \%$, rata-rata kelas naik menjadi 75,2 . Berdasarkan pengamatan tersebut dapat diketahui bahwa proses pembelajaran pada siklus pertama belum berhasilmaksimaldan belum mencapai indikator kinerja yang diharapkan. Peningkatan hasil, jika dibandingkan hasil prasiklus yang mencapai KKM sebanyak 17 siswa atau $53,1 \%$ setelas diberi tindakan penerapan siklus I, siswa yang mencapai KKM sebanyak 23 siswa atau $71,8 \%$.

Tabel 1.Perkembangan Siswa yang Mencapai KKM Prasiklus ke Siklus I

\begin{tabular}{clcc}
\hline No & Prestasi Siswa & Prasiklus & Siklus I \\
\hline 1 & Rata-rata & 70,1 & 75,2 \\
\hline 2 & Siswa mencapai KKM & 17 & 23 \\
\hline
\end{tabular}

Dari tabel di atas dapat disimpulkan bahwa prestasi belajar bahasa Inggris materi menulis teks procedure pembelajaran kooperatif tipe make a match, padapelaksanaan tindakan siklus I mengalami peningkatan. Sebelum dilakukan tindakan atau prasiklus, ratarata prestasi belajar siswa sebesar 70,1 dan siswa yang mencapai KKM sebanyak 17 siswa, setelah tindakan siklus I, rata-rata prestasi belajar siswa menjadi 75,2 dan siswa yang mencapai KKM sebanyak 23 siswa sehingga meningkat 6 siswa. Setelah dievaluasi bersama dari pelaksanaan tindakan pada siklus I yang digunakan sebagai bagian pertimbangan perencanaan pembelajaran siklus berikutnya, dengan perencanaan perbaikan untuk mengatasi kekurangan dan kesalahan yang dilakukan pada siklus I. Tindakan kelas siklus II dilaksanakan pada hari Rabu, 11 September 2019 dengan materi menulis teks procedure menunjukan adanya peningkatan yang signifikan. Rata-rata nilai prestasi belajar siswa kelas IXC naik menjadi 80 dan sebanyak 29 siswa $(90,6 \%)$ mencapai nilai KKM.

Tabel 2. Perkembangan Prestasi Belajar Siswa dari Siklus I ke Siklus II

\begin{tabular}{clcc}
\hline No & Prestasi Siswa & Siklus I & Siklus II \\
\hline 1 & Rata-rata & 75,2 & 80 \\
\hline 2 & Siswa mencapai KKM & 23 & 29 \\
\hline
\end{tabular}

Dari tabel di atas dapat disimpulkan bahwa prestasi belajar bahasa Inggris materi menulis teks procedure dengan menerapkan model pembelajaran kooperatif tipe make a match, padapelaksanaan tindakan siklus II mengalami peningkatan. Pada tindakan siklus I, rata-rata prestasi belajar siswa sebesar 75,2 dan siswa yang mencapai KKM sebanyak 23 siswa, setelah tindakan siklus II,rata-rata prestasi belajar siswa menjadi 80 dan siswa yang mencapai KKM sebanyak 29 siswa sehingga meningkat6 siswa.Berdasarkan hasil tersebut dapat diketahui bahwa proses pembelajaran sampai dengan pada siklus II berjalan dengan baik dan telah memenuhi indikator kinerja yang diharapkan. Pada siklus I dan II dengan penerapan tindakan menggunakan model pembelajaran kooperatif tipe make a match, siswa lebih antusias dengan perasaan senang dalam mengikuti kegiatan pembelajaran.

Tabel 3. Perkembangan Prestasi Belajar Siswa Prasiklus,Siklus I dan Siklus II

\begin{tabular}{llccc}
\hline No & Prestasi Siswa & Prasiklus & Siklus I & Siklus II \\
\hline 1. & Rata-rata & 70,1 & 75,2 & 80 \\
\hline 2. & Siswa mencapai KKM & 17 & 23 & 29 \\
\hline
\end{tabular}


Dari tabel di atas dapat disimpulkan bahwa hasil belajar materi menulis teks procedure dengan menerapkan model pembelajaran kooperatif tipe make a match, di setiap pelaksanaan tindakan, baik siklus I dan siklus II mengalami peningkatan, yaitu: siswa yang mencapai KKM sebelum dilakukan tindakan atau prasiklus 17 siswa, setelah tidakan siklus I sebanyak 23 siswa dan setelah tindakan siklus II sebanya 29 siswa, sehingga peningkatan kumulatif dari sebelum tindakan/prasiklus sampai dengan siklus II sebesar 12 siswa.

Tabel 4. Perkembangan Persentase Siswa Mencapai KKM Prasiklus, Siklus I dan Siklus II

\begin{tabular}{ccccc}
\hline No & Prestasi Siswa & Prasiklus & Siklus I & Siklus II \\
\hline & Persentase Siswa & $53,1 \%$ & $71,8 \%$ & $90,6 \%$ \\
Mencapai KKM & & & \\
\hline
\end{tabular}

Dari tabel di atas dapat disimpulkan bahwa prestasi belajar bahasa Inggris materi menulis teks procedure menerapkan model pembelajaran kooperatiftipemake a match, di setiap pelaksanaan tindakan mengalami peningkatan, yaitu:persentase siswa yang mencapai KKM sebelum dilakukan tindakan atau prasiklus 53,1\%, setelah tidakan siklus I sebanyak 71,8\% dan setelah tindakan siklus II sebanya 90,6\%.

Tabel 5. Perkembangan Nilai Rata-rata Kelas Prasiklus, Siklus I dan Siklus II

\begin{tabular}{|c|c|c|}
\hline & $\begin{array}{l}\text { Prestasi Siswa } \\
\text { Nilai rata-rata }\end{array}$ & $\begin{array}{c}\text { Prasiklus } \\
70.1\end{array}$ \\
\hline
\end{tabular}

Dari tabel di atas dapat disimpulkan bahwa prestasi belajar materi menulis teks procedure dengan menerapkan model pembelajaran kooperatif tipe make a match, di setiap pelaksanaan tindakan mengalami peningkatan, yaitu: nilai rata-rata kelas sebelum dilakukan tindakan atau prasiklus adalah 70,1, setelah tidakan siklus I adalah 75,5 dan setelah tindakan siklus II adalah 80 sehingga dari kondisi awal sebelum tindakan/prasiklus sampai dengan tidakan pada siklus II terjadi peningkatan.Dari uraian di atas dapat disimpulkan bahwa model pembelajaran kooperatif tipe make a match dapat meningkatkan prestasi belajarmateri menulis teks procedure siswa kelas IXC SMP Negeri 1 Bulu semester 1 tahun pelajaran 2019/2020.

\section{Pembahasan}

Pada penelitian kondisi awal diperoleh data yang dapat ditabulasikan sebagai berikut:

Tabel 6. Nilai Hasil Pengamatan awal

\begin{tabular}{cc}
\hline Nilai & Test Individual \\
\hline Terendah & 55 \\
\hline Tertinggi & 89 \\
\hline Jumlah & 2243 \\
\hline Rata-rata & 70,1 \\
\hline Persentase ketuntasan & $53,1 \%$
\end{tabular}

Pada siklus I diperoleh data yang dapat ditabulasikan sebagai berikut:

Tabel 7. Nilai Hasil Pengamatan Siklus I

\begin{tabular}{cc}
\hline Nilai & Test Individual \\
\hline Terendah & 59 \\
\hline Tertinggi & 93 \\
\hline Jumlah & 2408 \\
\hline Rata-rata & 75,2 \\
\hline Persentase ketuntasan & $71,8 \%$ \\
\hline
\end{tabular}


Pada siklus II diperoleh data yang dapat ditabulasikan seperti berikut:

Tabel 8. Nilai Hasil Pengamatan Siklus II

\begin{tabular}{cc}
\hline Nilai & Test Individual \\
\hline Terendah & 70 \\
\hline Tertinggi & 94 \\
\hline Jumlah & 2560 \\
\hline Rata-rata & 80 \\
\hline Persentase ketuntasan & $90,6 \%$
\end{tabular}

Tabel 9. Profil Kelas Sebelum dan Sesudah Tindakan Penelitian

\begin{tabular}{|c|c|c|c|c|c|}
\hline No & Hasil Siswa & & Kondisi Awal & Siklus I & Siklus II \\
\hline 2 & Nilai rata-rata & & 70,1 & 75,2 & 80 \\
\hline 3 & $\begin{array}{ll}\text { Siswa yang } \\
\text { KKM }\end{array}$ & tuntas & $\begin{array}{l}\text { 17siswa } \\
(53,1 \%)\end{array}$ & $\begin{array}{l}23 \text { siswa } \\
(71,8 \%)\end{array}$ & $\begin{array}{l}29 \text { siswa } \\
(90,6 \%)\end{array}$ \\
\hline
\end{tabular}

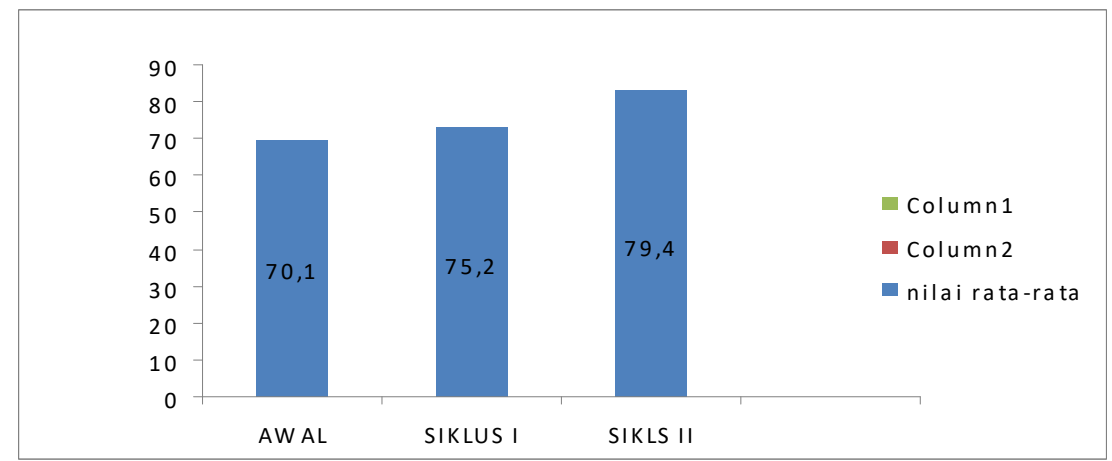

Gambar 1. Rata-rata Prestasi Belajar Siswa pada Kondisi Awal, Siklus I, dan Siklus II

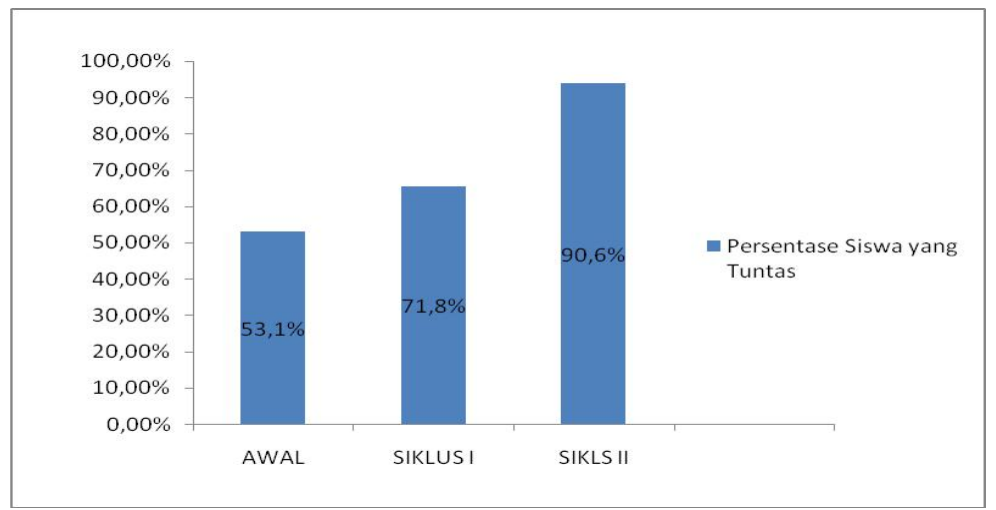

Gambar 2. Persentase Ketuntasan Siswa pada Kondisi Awal, Siklus I, dan Siklus II

Berdasarkan grafik di atas dapat ditunjukkan bahwa prestasi belajar siswa dengan menerapkan pembelajaran model kooperatif tipe make a match di setiap putaran mengalami peningkatan, yaitu: (1) Sebelum dilakukan tindakan penelitian kelas nilai rata-rata hasil belajar siswa adalah 70,1 dengan presentase prestasi belajar siswa hanya 53,1\%, (2) Setelah dilakukan tindakan pada siklus I nilai rata-rata prestasi belajar siswa mengalami 
peningkatan yaitu 75,2 dengan presentase ketuntasan 71,8\%, tetapi belum mencapai indikator yang diharapkan; (3) Pada siklus II nilai rata-rata prestasi belajar siswa meningkat yaitu menjadi 80 dengan presentase ketuntasan sebesar 90,6\% dan sudah mencapai indikator yang diharapkan maka penelitian tindakan kelas ini sudah berhasil. Rata-rata prestasi belajar siswa pada kondisi awal 70,1 dengan persentase ketuntasan belajar siswa sebesar 53,1\%, pada siklus II naik menjadi $80 \geq 80,0$ (indikator kinerja) dengan presentase ketuntasan belajar siswa sebesar $90,6 \geq 85 \%$ (indikator kinerja). Jadi, indikator kinerja sudah tercapai sehingga tidak dilanjutkan ke siklus berikutnya.

\section{Simpulan dan Saran}

Berdasarkan hasil penelitian dapat disimpulkan bahwa: "Model pembelajaran kooperatif tipe make a match dapat meningkatkan prestasi belajar Bahasa Inggris siswa kelas IXC semester 1 SMP Negeri 1 Bulu tahun pelajaran 2019/2020. Hasil penelitian ini menunjukkan adanya peningkatan pada prestasi belajar bahasa Inggris siswa. Hal ini dapat dilihat dari nilai rata-rata prestasi belajar bahasa Inggris siswa juga mengalami peningkatan yaitu sebelum tindakan sebesar 70,1, pada siklus I sebesar 75,2 dan pada siklus II sebesar 80. Selain itu, persentase ketuntasan belajar siswa, yaitu sebelum tindakan sebesar $53,1 \%$, pada siklus I sebesar 71,8\% dan pada siklus II sebesar 90,6\%. PTK yang dilaksanakan di SMP Negeri 1 Bulu ini sudah berjalan dengan cukup baik dan hasil yang baik pula. Namun masih banyak hal yang perlu diperbaiki. Oleh karena itu, peneliti memberikan beberapa saran. Dalam mengikuti pembelajaran bahasa Inggris disarankan siswa dapat kooperatif dalam berkooperatifitas dikelas baik saat kegiatan belajar mengajar (KBM) ataupun saat berdiskusi kelompok. Sehingga dapat meningkatkan pemahaman materi yang sedang diajarkan dan dapat meningkatkan prestasi belajar siswa yang optimal sehingga dapat mencapai melebihi KKM. Guru bahasa Inggris hendaknya dapat menumbuh kembangkan kreativitas dalam menjalankan profesinya sebagai fasilitator dan motivator dalam menyampaikan pembelajaran secara kooperatif dan inovatif pada siswa dalam penyampaian materi, sehingga siswa dapat menerima dan memahami materi yang diajarkan dengan baik. Sekolah disarankan mengadakan rapat uintuk membahas model pembelajaran yang inovatif dan menyenangkan seperti model pembelajaran kooperatiftipe Make a match untuk diterapkan dalam pembelajaran. Agar lebih meningkatkan kekooperatifan siswa dan prestasi belajar siswa dalam belajar bahasa Inggris. PTK ini diharapkan akan membawa dampak positif terhadap perkembangan sekolah yang nampak pada peningkatan prestasi belajar siswa sehingga dapat meningkatkan prestasi dan kualitas sekolah.

\section{Daftar Rujukan}

Arikunto, Suharsimi. (2006). Prosedur Penelitian. Jakarta: Rineka Cipta

Sardiman A.M. (2010). Interaksi dan Motivasi Belajar Mengajar. Jakarta:

PT Raja Grafindo Persada.

Sudiyana. (2012). Penelitian Tindakan Kelas. Yogyakarta: Cakrabooks dan Bradelvi.

Suprijono, Agus. (2013). Cooperative Learning Teori dan Aplikasinya. Yogyakarta: Pustaka Pelajar.

Warsono,Hariyanto. (2013). Pembelajaran Kooperatif Teori dan Assesmen. Bandung: PT Remaja Rosdakarya Offset. 